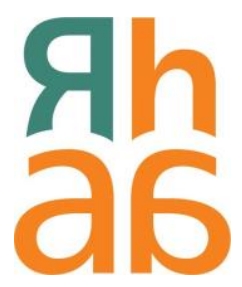

\title{
La construcción de las bibliotecas populares en Chile: Sarmiento, el libro y la lectura (1840-1856)
}

\section{The construction of popular libraries in Chile: Sarmiento, the book and reading (1840-1856)}

\author{
Raquel Soaje de Elías \\ Universidad de Los Andes \\ Chile \\ (iD https://orcid.org/0000-0003-0825-4454 \\ rsoaje@uandes.cl \\ Felipe Molina Jarpa \\ Universidad de Los Andes \\ Chile \\ (D) https://orcid.org/0000-0001-5754-113X \\ fmolinaja@gmail.com
}

\section{Resumen}

Este artículo tiene dos objetivos. El primero de ellos reconstruir el proceso que dio origen a las bibliotecas populares en Chile a partir del contexto político, ideológico y cultural de mediados del siglo XIX. En segundo término, analizar el rol de Domingo Faustino Sarmiento como promotor de esta política pública. Las fuentes sobre las cuales se articula el estudio son principalmente artículos de prensa, documentos oficiales y libros de la época, en donde quedó registrada la huella de aquella iniciativa tempranamente truncada. A partir de lo anterior, se logró identificar cómo el proyecto de las bibliotecas populares, ideado por el sanjuanino, nació a partir de la necesidad que existía de difundir el libro y orientar la práctica lectora, a partir de criterios de utilidad claramente definidos y compartidos por la elite dirigente. 
Además, se constató cómo confluyeron en este proyecto bibliotecario las ideas de Sarmiento sobre la educación popular y sus propios intereses en el negocio de la imprenta.

Palabras clave: Sarmiento; Bibliotecas populares; Chile; Libros; Educación.

\begin{abstract}
This article has two main objectives. The first, reconstruct the process that gave rise to popular libraries in Chile from the political, ideological and cultural context of the mid-nineteenth century. The second, seeks to analyze the role played by Domingo Faustino Sarmiento as a promoter of this public policy. The sources on which this study is constructed are mainly press articles, official documents and contemporary books, places where the trace of that early truncated initiative was recorded. From the above, it was possible to identify how the popular libraries project, devised by Sarmiento, was born from the need that existed to promote the book and guide reading practice, based on clearly defined and shared utility criteria by the ruling elite. In addition, it was verified how Sarmiento's ideas about popular education and his own interests in the printing business converged in this library project.
\end{abstract}

Key words: Sarmiento; Popular libraries; Chile; Books; Education.

Recibido: 17/02/2020 Aceptado: 01/12/2020

\title{
Introducción
}

En Chile, en pleno siglo XIX, existió a lo largo del país una cadena de bibliotecas públicas de préstamo, sostenidas por el Estado. Promovidas a partir de 1852 desde las páginas de El Monitor de las Escuelas Primarias ${ }^{1}$ por el argentino Domingo Faustino Sarmiento y creadas durante el gobierno de Manuel Montt en $1856^{2}$, estas bibliotecas encontraron un abrupto final en $1865^{3}$. Tras casi diez años de existencia, las llamadas bibliotecas populares acabaron siendo un fracaso. El rastreo de su funcionamiento, de acuerdo con los testimonios de la época corroboran esta afirmación, lo cual ha dado lugar a otro estudio ya en curso. Si bien este episodio ha suscitado escaso

${ }^{1}$ Desde ahora El Monitor.

${ }^{2}$ Boletín de Leyes y Decretos (BLD), Libro XXIV, (1), Santiago de Chile, 1856, pp. 68. Recuperado de https://catalog.hathitrust.org/Record/000063525

${ }^{3}$ Revista Anales de la Universidad de Chile (AUCH), Tomo 27, Santiago de Chile, 1865, p. 406. Recuperado de https://anales.uchile.cl/index.php/ANUC/issue/archive

RHAA v.56 n.2, 2021. ISSN: 0556-5960, ISSNe 2314-1549. CC BY-NC-SA 4.0 
interés por parte de la investigación histórica a lo largo de los años (Muñoz, 2019; Poblete, 2017), el análisis minucioso de esta iniciativa nos permite comprender, desde una nueva óptica, el plan modernizador llevado a cabo por las elites gobernantes del país tras la independencia, el verdadero rol que jugaron los sectores populares como motivantes de aquel plan y la influencia que tuvieron sobre dicha élite los intelectuales-pedagogos (Stuven, 2008), como fue el caso de Sarmiento.

A partir de estos antecedentes, cabe cuestionarse acerca del contexto histórico desde el cual fueron pensadas y proyectadas las bibliotecas populares, cómo se gestó aquella iniciativa, cuál era el público objetivo al que se apuntaba, qué ideas y propósitos impulsaban el proyecto, y cuál fue el rol interpretado por Sarmiento en este proceso. Son estas las interrogantes que nos mueven, y que, a su vez, nos ayudan a delinear los objetivos hacia los cuales se dirige este estudio. El primero de ellos apunta a reconstruir el proceso que dio origen a las bibliotecas populares en Chile a partir del contexto político, ideológico y cultural de mediados del siglo XIX. En segundo término, se busca analizar el rol que cumplió Sarmiento como promotor de esta política pública, las ideas del argentino relacionadas al fomento y orientación de la práctica lectora, además de sus conocimientos, experiencias y expectativas acerca de la industria del libro.

En el plano espacial, este estudio se restringe únicamente a la situación de las bibliotecas populares en Chile. Cabe acotar al respecto, que instituciones de este tipo también existieron, y en algunos casos continúan existiendo, en Estados Unidos, Argentina (Planas, 2017), Brasil (Schapochnik, 2018) y España (Gómez, 1993), incluso con la misma antigua denominación. En el plano temporal, este trabajo está acotado al periodo comprendido entre 1840 y 1856, etapa que encierra la estadía de Sarmiento en Chile, en la cual se vivieron importantes cambios culturales y educacionales en el país ${ }^{4}$. Además, en esta etapa se produjo la gestación de dichas bibliotecas, entre los años 1852 y 1856, proceso que culminó con el decreto de creación de estas. Por último, cabe aclarar que el artículo excluye el periodo de funcionamiento transcurrido entre 1856 y 1865 , que forma parte de una investigación en curso, aun cuando se incorpora un listado de los libros editados hasta 1860, como prueba de la preponderancia

\footnotetext{
${ }^{4}$ Sarmiento había estado previamente en Chile entre los años 1831 y 1836 . Su segunda estadía, caracterizada por su actividad pública, se extiende desde 1840 hasta 1856.
}

RHAA v.56 n.2, 2021. ISSN: 0556-5960, ISSNe 2314-1549. CC BY-NC-SA 4.0 
que adquirió la imprenta de Sarmiento en la materialización de esta empresa.

\section{Las bases de la propuesta}

\section{Los libros piden escuelas, las escuelas piden libros}

Durante el siglo XIX, la elite dirigente del país estuvo inmersa en la construcción del Estado republicano. La creación de este nuevo orden exigía no solo la virtud política de sus miembros, sino también, la unidad de estos bajo el concepto de lo nacional. La educación fue vista como el modo más efectivo de infundir ambos elementos como parte del espíritu de la época ${ }^{5}$ (Aedo Richmond, 2000; González Miranda, 2002; Caruso, 2010; Mayorga, 2010; Serrano, Ponce de León y Rengifo, 2012; Toro Blanco, 2018; Cucuzza, 2018; Baeza Ruz, 2019). Concebida como un agente transformador para la "regeneración del pueblo", la educación se erigió en pilar estructural de la sociedad inaugurada tras la emancipación.

Está ampliamente demostrado, y se puede rastrear incluso a partir de las normativas promulgadas ya desde 1813, que se concebía la educación como un asunto de la sociedad y del Estado (Serrano, 2016). En este sentido, cabe resaltar, por una parte, que la preocupación por la alfabetización de la población se hizo presente desde los primeros momentos del periodo independiente. La creación del Instituto Nacional en 1813, o bien la introducción del sistema lancasteriano de enseñanza de la lectura en 1821 (Baeza Ruz, 2018), demuestran la inquietud de los primeros gobiernos patrios por esta arista clave para el nuevo sistema republicano. Sin embargo, y debido en buena medida a las prioridades políticas del momento, durante las primeras décadas de vida independiente la provisión de la educación, sobre todo a nivel elemental, fue relegada, en parte, a la iniciativa privada, vinculada a las órdenes religiosas, como las de San Francisco, Santo Domingo y mercedaria. También se encargaron de ella las

\footnotetext{
${ }^{5}$ Existe una copiosa historiografía acerca del rol crucial de la educación para la construcción republicana, no solo respecto a Chile, sino también a América latina, tanto desde la instrucción pública como privada, nacional como regional, e incluso en su relación con otros países. Además, cabe destacar el interés por la historia de la lectura tanto en Chile, como en otros países latinoamericanos.
} 
Sociedades bíblicas protestantes, entre 1817 y 1831 (Baeza Ruz, 2019) ${ }^{6}$, los antiguos cuerpos coloniales, como los municipios y parroquias (Newland, 1991; Serrano et al., 2012), o bien, grupos de vecinos, organizados en torno a alguna modalidad de suscripción (Serrano et al., 2012). A partir de 1837, con la erección del Ministerio de Educación incorporado al de Justicia y Culto, se creó también la categoría de escuela fiscal, siendo minoría hasta, por lo menos, 1860. En efecto, la Constitución de 1833, había consagrado el principio del deber del Estado en esta materia y, consolidado, así, los cimientos del llamado "Estado docente". Más tarde, la promulgación de la Ley Orgánica de 1842, que dio vida a la Universidad de Chile, y paralelamente, la creación de la Escuela Normal de preceptores, institución crucial para la formación de un nuevo profesorado de nivel primario, hicieron posible que aquel orden jurídico instaurado por la constitución comenzara a plasmarse en la realidad. En la Universidad se instaló la Superintendencia de Educación, que cumplió las labores de dirección e inspección nacional en todos sus niveles (Serrano, 2016) ${ }^{7}$. En este marco, se inició un proceso estatal de expansión y modernización de la instrucción primaria en Chile (Egaña Baraona, 2000), como así también de su laicización, a partir de dicho nivel, el primero que aspiraba a ser universal.

A través de la acción escolar se buscaba, principalmente, difundir la lectoescritura en la gran masa analfabeta de la población. La expansión de la cultura escrita se consideraba un imperativo de la civilización, ya que sus mismísimas bases estaban enraizadas en el conocimiento de las letras (Serrano y Jaksic, 2000). Así, con el correr de los años, y tal como se puede observar en los cuadros 1 y 2, las escuelas se multiplicaron por el territorio, los índices de escolarización en el país comenzaron a crecer y las habilidades escritas poco a poco se extendieron entre la población. Todo este movimiento se produjo de forma lenta pero constante en el tiempo. En Chile, la alfabetización fue un producto directo de la escuela (Serrano et al., 2012).

\footnotetext{
${ }^{6}$ El estudio de Baeza Ruz (2019) destaca la actuación de James Thomson, misionero protestante, y "doble agente de la British and Foreign Bible Society y de la Britisch and Foreign School Society", para la adopción del sistema que los agentes protestantes idearon para lograr adeptos a sus credos, mediante la prédica sobre la liberación de Hispanoamérica de la opresión de la Iglesia Católica, paralelamente a su emancipación de la monarquía española.

${ }^{7}$ Ese rol general residió en el Consejo Universitario, mientras que la Facultad de Filosofía y Humanidades asumió la instrucción primaria.
} 
Cuadro 1: Estructura del sistema de instrucción primaria, 1855-1865

\begin{tabular}{|c|c|c|c|c|c|c|}
\hline Año & \multicolumn{3}{|c|}{ Número de escuelas } & \multicolumn{3}{c|}{ Número de alumnos } \\
\hline & Públicas & Particulares & Total & Públicas & Particulares & Total \\
\hline 1855 & 398 & 299 & 697 & 20.100 & 8.717 & 28.817 \\
\hline 1865 & 599 & 437 & 1.036 & 38.439 & 12.855 & 51.294 \\
\hline
\end{tabular}

Fuente: Serrano, Ponce de León y Rengifo, 2012, pp. 367-369

Cuadro 2: Número de individuos que saben leer, 1854-1865

\begin{tabular}{|c|c|c|c|}
\hline Año & $\begin{array}{c}\text { Población mayor de } \\
7 \text { años }\end{array}$ & $\begin{array}{c}\text { Saben leer mayores } \\
\text { de } 7 \text { años }\end{array}$ & $\begin{array}{c}\text { Leen de cada 100 } \\
\text { habitantes }\end{array}$ \\
\hline 1854 & 1.214 .264 & 170.016 & 14,0 \\
\hline 1865 & 1.460 .123 & 299.704 & 20,5 \\
\hline
\end{tabular}

Fuente: Serrano, Ponce de León y Rengifo, 2012, p. 374

No obstante, aprender a leer y a escribir no dejaba de ser más que un primer paso para la transformación que se intentaba llevar a cabo: "La instrucción primaria -explicaban los hermanos Amunátegui (1856) en su obra De la instrucción primaria en Chile: lo que es, lo que debería ser - es uno de los principios que conducen a la civilización, pero no es la civilización" (p. 83). En esa lógica, la escuela debía verse continuada por el libro, objeto concebido como la gran herramienta de instrucción. En el imaginario de aquellos hombres, el libro era, en palabras de Subercaseaux (2010), un "vehículo insustituible de pensamiento, de ideas, de conocimientos (...) el instrumento único y por excelencia para educar no solo a niños, sino a los pueblos y a los países" (p. 61). En consecuencia, el fomento del libro era el aspecto fundamental del esfuerzo civilizador.

Instalado en Chile desde comienzos de la década del cuarenta, Sarmiento comprendió y expresó toda esta problemática en la prensa, de forma bastante lúcida. “¿Cómo leer? ¿Qué leer? ¿Cuándo leer? es, en efecto, todo lo que importan los miles consagrados a la enseñanza, y el fruto que de ellos ha de sacarse ¡Toda la enseñanza pública viene a terminar ahí!"9, exclamaba enérgicamente el argentino en las páginas de El Monitor. Allí

\footnotetext{
${ }^{8}$ Desde ahora De la instrucción primaria.

${ }^{9}$ Sarmiento, D. F. Bibliotecas Locales. Periódico El Monitor de las Escuelas Primarias (MEP), Tomo I, (11), Santiago de Chile, 15-06-1853, p. 321. Recuperado de http://www.memoriachilena.gob.cl/602/w3-article-124167.html
}

RHAA v.56 n.2, 2021. ISSN: 0556-5960, ISSNe 2314-1549. CC BY-NC-SA 4.0 
manifestó la íntima relación entre la escuela y el libro con miras a la instrucción general de la población:

Haya libros, empero, ha dicho ya la experiencia, y las escuelas tendrán su razón de ser (...) la escuela y el libro (...) son dos cosas que se suponen la una a la otra. Los libros piden escuelas, las escuelas piden libros ${ }^{10}$.

\section{Difundir el libro y orientar su lectura}

A partir de 1840 el mundo del libro, y del impreso en general, experimentó en Chile un verdadero despertar que contrastó fuertemente con lo que sucedía en los años anteriores. Subercaseaux (2010) señala que, en la década de los cuarenta, y hasta 1880, en el país se crearon "las bases de la industria impresora" (p. 75). El mismo autor (2010) indica que hubo un importante aumento en la importación de insumos, tales como papel y tinta, y de máquinas de imprenta. Así, en el decenio de 1840-1850, cuando estaban en funcionamiento unas nueve imprentas en Valparaíso y otras más en ciudades como Santiago, Coquimbo, Talca y Concepción, entraron al país 23.306 resmas de papel y 23 máquinas de imprenta, mientras que en la década siguiente ingresaron 50.714 resmas y 16 máquinas más. Paralelamente, hubo un incremento en el número de trabajadores especializados; si en 1845 había en Chile 210 tipógrafos, agremiados desde 1853 en la Unión de Tipógrafos de Santiago, para 1865 ese número aumentó a 380 .

En cuanto a la producción, esta se concentró principalmente en la publicación de periódicos, los cuales, en su mayoría, poseían su propia imprenta, y conformaron, de esta manera, "una sola unidad empresarial" (Subercaseaux, 2010, p. 81). Complementariamente, hubo espacio para la producción de libros. José Victorino Lastarria señala que entre 1855 y 1865 se publicaron, en promedio, unos 72 títulos anuales, cifra que, entre los años 1865 y 1869, aumentó a 112 títulos (Lastarria, 1878). La energía de las imprentas estuvo puesta mayoritariamente en las traducciones y reimpresiones de autores europeos, que se elevaron sustancialmente entre 1850 y 1860, tal como se aprecia en el cuadro 3:

\footnotetext{
${ }^{10}$ Sarmiento, D. F. Bibliotecas Locales. MEP, Tomo I, (11), 15-06-1853, p. 321. Recuperado de http://www.memoriachilena.gob.cl/602/w3-article-124167. La cursiva es nuestra.
} 
Cuadro 3: Traducciones y reimpresiones. Chile, 1820-1860

\begin{tabular}{|c|c|}
\hline Década & $\begin{array}{c}\text { Número de traducciones } \mathrm{y} \\
\text { reimpresiones }\end{array}$ \\
\hline 1820 & 10 \\
\hline 1830 & 7 \\
\hline 1840 & 87 \\
\hline 1850 & 120 \\
\hline 1860 & 150 \\
\hline
\end{tabular}

Fuente: Subercaseaux, 2010, p. 84

Los espacios de circulación y consumo, encarnados en bibliotecas públicas y librerías, proliferaron de forma creciente. Vale la pena destacar la aparición del comercio especializado, inexistente en las primeras décadas de vida independiente, el cual tuvo como figura inaugural al español José Santos Tornero. En 1840, en la ciudad de Valparaíso, el oriundo de Logroño abrió las puertas de la primera librería del país, para crear, dos años más tarde, otra en la capital (Santos Tornero, 1889). Ya para 1849 existían, al menos, 5 de estos establecimientos solamente en Valparaíso (Subercaseaux, 2010). Toda esta transformación estuvo acompañada de una creciente preocupación relativa a la calidad y contenido de los libros que paulatinamente ocupaban un espacio visible en la vida de la nación.

En "Biblioteca americana", artículo publicado en 1849 en el periódico La Crónica, Sarmiento se preguntaba por los libros que circulaban en el país. Tras el escrutinio de la producción nacional, en la cual no encontraba más que textos escolares, novelas y alguno que otro libro original, la decepción se terminó por apoderar del sanjuanino ante el análisis de la producción europea que llegaba al país, y concluyó que tanto "allá como aquí, huyen las imprentas de dar a luz obra seria alguna" (Sarmiento, 1849a, p. 258). Unos años más tarde, insistiría sobre esta cuestión y reclamaría la dependencia de los cálculos comerciales de los libreros extranjeros, que publicaban lo que más salida tenía y no lo que más convenía a los nuevos ciudadanos: "No se imprimen sino novelas en América, y novelas y devocionarios en París y España para nosotros, porque para los libros útiles falta un mercado cuán grande es la América del Sud" (Sarmiento, 1854a, p. 250).

De modo similar, los hermanos Amunátegui (1856), tras consultar a los libreros sobre sus ventas anuales, estimaron que la tercera parte de estas correspondía a obras impresas en el país, "libros elementales que preparan,

RHAA v.56 n.2, 2021. ISSN: 0556-5960, ISSNe 2314-1549. CC BY-NC-SA 4.0 
pero no esos libros de estilo más elevado que contienen las aplicaciones, la ciencia" (p. 222). Los dos tercios restantes correspondían a textos importados, de los cuales se descartaban todas las novelas y obras ascéticas, ante lo cual sentenciaban: "Se ve por esto que es estremadamente (sic) reducido el número de libros provechoso para la ilustración que compramos anualmente" (p. 222). Conclusión parecida a la sostenida desde El Monitor, tras analizar el catálogo de una librería porteña: De sus 150 obras en castellano, se lee en las páginas del periódico dirigido por Sarmiento, un tercio eran de tono religioso, 19 eran novelas y 31 eran tratados de medicina, leyes o gramática. Así, aquel catálogo quedaba reducido drásticamente a solo 50 obras útiles, categoría compuesta por libros de historia, poesía y otras varías "de verdadera lectura popular"11. Después de aquel desglose, y con evidente desilusión, se interrogaba a los lectores: "¿si no se quedan como nosotros asombrados i (sic) tristes a la vez, de ver (...) esa ostentación de catálogos, que nada o poquísimo de sustancia contienen?"12.

Desde El Monitor, se analizó, además, el fondo bibliográfico de la Biblioteca Nacional, y se puso en tela de juicio la capacidad de esta institución para atraer lectores. De estos libros, se afirmaba, habría que "escluir (sic), como elementos de lectura para el público, la mayor parte"13. Tres eran las razones esgrimidas: la antigüedad de los libros, su extensión y la gran cantidad de textos en otras lenguas.

Respecto a la expansión de la práctica lectora la situación no era muy diferente. Debido al carácter laico y utilitarista de la nueva producción escrita, la Iglesia Católica observó todo este fenómeno como una potencial amenaza para la fe y la moral cristiana, planteó la necesidad de guiar al lector y, paralelamente, incentivar la lectura de buenos libros, través de sus diversas instituciones (Cherniavsky, 2015). Aquel discurso que orientaba la práctica de la lectura, no estaba restringido únicamente a las voces de la

${ }^{11}$ Biblioteca Nacional i Bibliotecas locales o parroquiales. MEP, Tomo II, (10), 15-081853 , p. 237. Recuperado de http://www.memoriachilena.gob.cl/602/w3-article124167.html

${ }^{12}$ Biblioteca Nacional i Bibliotecas locales o parroquiales. MEP, Tomo II, (10(, 15-081853 , p. 237. Recuperado de http://www.memoriachilena.gob.cl/602/w3-article124167.html

${ }^{13}$ Biblioteca Nacional i Bibliotecas locales o parroquiales. MEP, Tomo II, (10), 15-081853 , p. 235. Recuperado de http://www.memoriachilena.gob.cl/602/w3-article124167.html

RHAA v.56 n.2, 2021. ISSN: 0556-5960, ISSNe 2314-1549. CC BY-NC-SA 4.0 
Iglesia. Los hermanos Amunátegui (1856), hombres de impronta liberal, también manifestaron una preocupación similar, al señalar que la lectura podía constituir un arma de doble filo, puesto que capacitaba al individuo "para aprovechar las sabias lecciones de las buenas obras" (p. 213), pero, a su vez, lo exponía "a inficionarse con las perniciosas doctrinas de las malas" (p. 213). En consecuencia, planteaban, no era suficiente que el pueblo aprendiera a leer; era necesario, además, "proporcionarle libros instructivos y morales, que formen su corazón, que cultiven su inteligencia, que le indiquen los medios para ganar la vida" (pp. 216-217).

Observamos a partir de lo expuesto que, para una parte de la elite intelectual, no toda obra escrita era comprendida y apreciada como vehículo de conocimiento. Aquella era una cualidad propia de los libros calificados como útiles. El problema era que estos no eran los que se producían, circulaban y leían en el país. Así, y pese a que la formación de una sociedad lectora era un objetivo deseado, el crecimiento de esta práctica despertó cierta inquietud entre los sectores cupulares. En ese sentido, ya desde la década anterior, el ministro Varas se preguntaba: "¿Qué podemos prometernos de que se sepa leer si no hai (sic) lecturas apropiadas a las clases que viven de su diario trabajo?" (Citado de Poblete, 2017, p. 55). Esta doble necesidad sustentó el espacio desde el cual fueron pensadas y proyectadas las bibliotecas populares en Chile por Sarmiento, quien, pese a su sincera preocupación por la educación popular, se vio animado, también, por ciertos intereses individuales a la hora de concebir este proyecto.

\section{Con la mirada hacia el Norte}

Ciertamente, aquella propuesta no fue una idea original del argentino, por lo que cabe preguntarse hacia qué horizontes apuntaba su mirada a la hora de idear este proyecto bibliotecario. Durante el siglo XIX nuevas iniciativas relacionadas al campo del libro y la lectura, tanto de carácter público como privado, vieron la luz en Europa y los Estados Unidos. Aquellas eran el reflejo no solo del aumento progresivo de la masa letrada en el mundo occidental, sino también de los cambios de hábito y consumo en el público lector. Las sociedades literarias, los gabinetes de lectura, las bibliotecas de préstamo, entre otras, fueron parte de este conjunto inédito de iniciativas (Lyons, 2012). Todo esto llamó fuertemente la atención en el Chile de mediados del siglo XIX, específicamente la de aquellos hombres preocupados por la instrucción pública, los llamados intelectualespedagogos (Stuven, 2008), miembros de la afamada Generación del 42, quienes, movidos por el ideal del Progreso, concepto estructurante del

RHAA v.56 n.2, 2021. ISSN: 0556-5960, ISSNe 2314-1549. CC BY-NC-SA 4.0 
imaginario político e ideológico de la época, reflexionaron en torno a estos fenómenos con la intención de adaptar aquellas experiencias a la realidad nacional.

En este contexto surgió, en el seno del Instituto Nacional, la Sociedad Literaria de 1842. Liderada por José Victorino Lastarria, aquel grupo, inspirado en los principios del romanticismo imperante en la Europa de la primera mitad del siglo XIX, desempeñó un rol clave en la difusión de la lectura ${ }^{14}$. Su creación tuvo como antecedente el "trabajo formativo de José Joaquín Mora y Andrés Bello en la década del treinta" (Muñoz et al, 1993). De acuerdo con el testimonio de Jacinto Chacón, miembro de la referida agrupación, ciertos jóvenes distinguidos de la sociedad santiaguina se reunían en casa de Andrés Bello para leer a Byron, Víctor Hugo y Lamartine, para discurrir sobre los últimos adelantos de la ciencia y cultivar el espíritu ilustrado que los animaba (Chacón, 1924). Algunos de ellos, consideraban necesario remover un obstáculo fundamental para alcanzar aquel Progreso, identificado expresamente por Francisco Bilbao, en cuyo escrito "Sociabilidad chilena", denunciaba "que el clero ejercía un dominio absoluto sobre las familias y que esta influencia de todos los instantes atrofiaba a la sociedad impidiendo su desarrollo y su progreso" (Chacón, 1924, el subrayado es nuestro).

En pos del mismo ideal, una década después, los hermanos Amunátegui (1856) analizaron el caso francés de las bibliotecas de préstamo y constataron la existencia, a finales del siglo XVIII, de pequeños kioscos privados, que por medio de suscripciones permitían al usuario alquilar un libro o un periódico por un periodo de tiempo determinado, y lo contrastaban con la experiencia de los Estados Unidos. En este país desde la década de 1830, había pequeñas bibliotecas públicas de préstamo, en los distritos escolares de Nueva York y Massachusetts. A diferencia de los gabinetes franceses, cuya oferta de libros, guiada por los intereses de la industria, "no es mui (sic) esmerada ni en cuanto a la moralidad, ni en cuanto al mérito práctico ni literario" (p. 237), los repositorios norteamericanos "no contienen principalmente novelas como los análogos de la Francia, sino libros útiles, serios, de esos que alimentan el espíritu i (sic) fortifican el corazón" (p. 239).

\footnotetext{
${ }^{14}$ Sarmiento utilizó algunos de sus escritos como lectura para la primera generación de preceptores forjada bajo su alero.
}

RHAA v.56 n.2, 2021. ISSN: 0556-5960, ISSNe 2314-1549. CC BY-NC-SA 4.0 
Fue precisamente el modelo de las otrora trece colonias el que mayor influencia tuvo en la propuesta bibliotecaria de Sarmiento. Un estímulo prematuro para el sanjuanino había sido la Autobiografía de Benjamin Franklin. En esta obra, el norteamericano rememoraba su participación en la fundación de la biblioteca pública de Filadelfia en 1731, nacida a raíz de la sociedad literaria de la que él mismo había sido miembro. Sarmiento, nos cuenta Planas (2017), "percibió en Autobiografía una manera practicable y económica de ampliar los límites sociales de acceso al libro" (p. 32). A estas ideas tempranas, donde el acento estaba puesto en la iniciativa privada, se sumaron más tarde los conocimientos adquiridos durante su viaje por Europa y Estados Unidos ${ }^{15}$. Fue allí, seguramente, donde Sarmiento conoció de cerca los sistemas bibliotecarios de Nueva York y Massachusetts. En los Estados Unidos, se explicaba en las páginas de El Monitor, "se convencieron los que estudiaban las cuestiones relativas a la instrucción primaria, que era ineficaz para civilizar, sino se preparaba una serie de libros en que el público pudiese adquirir conocimientos" 16 .

En la política bibliotecaria norteamericana, complemento de su sistema educativo, se vio una de las razones que explicaban el progreso y la prosperidad de la poderosa nación del norte. Los chilenos, atónitos ante el veloz desarrollo experimentado por los Estados Unidos, identificaron a la educación -junto con la inmigración- como una de las claves para comprenderlo (Collier, 2005). En ese sentido, Miguel Luis Amunátegui reflexionaba en torno a la propuesta bibliotecaria de Sarmiento: "Era ya tiempo de que imitáramos lo que desde años se está practicando en los Estados Unidos, i (sic) lo que sin duda constituye uno de los principales elementos de la asombrosa prosperidad de esa república"17.

\section{El proyecto editorial de Sarmiento}

La idea de la biblioteca popular en Sarmiento constituye, en realidad, el corolario de una inquietud por la industria editorial que manifestó el sanjuanino desde su juventud. Ya desde su arribo a Chile en 1840, se había

\footnotetext{
${ }^{15}$ Entre 1845 y 1848, comisionado por el gobierno de Manuel Bulnes, Sarmiento emprendió un viaje por Europa y los Estado Unidos con el objetivo de estudiar sus sistemas de educación y adaptarlos a las necesidades locales.

${ }^{16}$ Biblioteca Nacional i Bibliotecas locales o parroquiales. MEP, Tomo II, (10), 15-081853, p. 240. Recuperado de http://www.memoriachilena.gob.cl/602/w3-article124167

${ }^{17}$ Amunátegui, M. L. Bibliotecas populares. MEP, Tomo III, (1), 15-08-1854, p. 15.

RHAA v.56 n.2, 2021. ISSN: 0556-5960, ISSNe 2314-1549. CC BY-NC-SA 4.0
} 
mostrado interesado por el mercado de los libros. En 1841 escribió un artículo para El Mercurio titulado "La publicación de libros en Chile". En él explicaba que el atraso del mercado editorial en este país se debía principalmente a los altos costos de producción, además de la carencia de libros útiles y de un público lector (Sarmiento, 1841). Al año siguiente, como fundador y redactor de El Progreso, se preocupó por preparar ese público por medio de la prensa, introdujo temáticas útiles, nuevos tipos de materiales y técnicas modernas como la litografía que incorporaba imágenes. Según observa Hernán Pas (2013), en esa época "los periódicos eran plataformas de experimentación pública" (p. 122). También participó activamente en los debates en torno a la legislación sobre la industria de la imprenta (Sarmiento, 1844). Pero más le inquietaba aún el problema del financiamiento, para lo cual intentaba captar suscriptores, dada la eficacia de esta táctica en el extranjero. Al estudio de esos aspectos se sumó la atención prestada al oficio de tipógrafo, en el artículo titulado "Aprendices de imprenta", donde indicaba los conocimientos y habilidades que debía poseer quien postulase para el oficio (Sarmiento, 1849b).

Este interés en el negocio de la imprenta se manifestó de modo explícito en ocasión del viaje que realizó al extranjero como comisionado del gobierno chileno. Según relata él mismo, en 1846 tuvo la oportunidad de conocer, en Saint Cloud, Francia, al joven Jules Belin, perteneciente a una prestigiosa casa de libreros franceses, a quien le propuso venir a América y establecer "una imprenta colosal, así que cayese el tirano Rosas" (Sarmiento, 1886, p. 28). En 1848, Belin ya se hallaba instalado en Santiago, y había transformado la antigua editorial de La Opinión, en la Imprenta Julio Belin y Cia., con el apoyo económico y la asesoría de Sarmiento. Al año siguiente ya había realizado varias publicaciones, entre las que se contaban traducciones al castellano, como el drama Teresa, y arreglado al teatro chileno por Andrés Bello, así como algunas otras realizadas con fines escolares por el propio Sarmiento, como un manual de historia antigua, y otro titulado ¿El por qué? o la Física. Mientras tanto, Belin se convertía en yerno de Sarmiento al casarse con su hija Ana Faustina, con lo cual la relación comercial con el joven francés se transformaría en familiar (Cabo, 2016).

De esta manera, iniciada la década del cincuenta, Sarmiento ya contaba con un socio y un editor capacitado para formar a los aspirantes en el oficio de tipógrafo, además de la propia experiencia y los conocimientos para concretar el proyecto de aquella "imprenta colosal" con la que había entusiasmado al joven Belin para cruzar el Atlántico. Sin embargo, le faltaba 
el financiamiento. No es extraño que, en su obra De la educación popular, Sarmiento sugiriera al Estado apoyar monetariamente la producción en gran escala de libros útiles (Sarmiento, 1849c). Podría así completar su carrera de escritor y publicista con la de editor de sus propios libros, y conjugar estas facetas con sus ideas de educación popular (Cabo, 2018). Con este fin se conformó la empresa antes mencionada, en la cual participaron posteriormente, además de Sarmiento y Belin, Ramón Rengifo como socio y el argentino Juan María Gutiérrez como corrector de pruebas (Campobassi, 1975).

\section{La propuesta bibliotecaria de Sarmiento}

En agosto de 1852 Sarmiento fue designado director y redactor del periódico El Monitor ${ }^{18}$. Desde esta publicación mensual, inició una verdadera campaña publicitaria para dar a conocer la idea de las bibliotecas populares y la conveniencia de su adopción para Chile. Esta propuesta, nos cuenta él mismo, fue "recibida con regular favor por varios órganos de prensa, y [despertando] simpatías aun en aquellas personas que más lejano miran todo progreso entre nosotros"19. El Ministro de Instrucción, Silvestre Ochagavía, en su memoria de 1853, ya hacía eco de estas ideas que circulaban por la prensa, y manifiestaba la responsabilidad del gobierno en esta materia: "Hay puntos de la República en que convendría ya ensayar la introducción de establecimientos que en otros países están produciendo excelentes resultados: hablo de las bibliotecas populares" 20 .

Paralelamente, la Imprenta Julio Belin y cia. sufrió un duro revés con el decreto del 19 de diciembre de 1853, por el cual el gobierno se hizo cargo de la edición de "textos de lectura i (sic) demás publicaciones elementales" 21 en gran escala, para su distribución gratuita en las escuelas fiscales a los alumnos de escasos recursos, y al precio de costo para los demás

${ }^{18} \mathrm{MEP}$, Tomo I, (1), 15-08-1852, pp. 1-2. Recuperado de http://www.memoriachilena.gob.cl/602/w3-article-124167.html

${ }^{19}$ Sarmiento, D. F. Bibliotecas Locales. MEP, Tomo I, № 12, 15-07-1853, p. 357. Recuperado de http://www.memoriachilena.gob.cl/602/w3-article-124167.html

${ }^{20}$ Memoria que el Ministro de Estado en el Departamento de Justicia, Culto e Instrucción Pública presenta al Congreso Nacional de 1853. MEP, Tomo II, (1), 1508-1853, p. 20. Recuperado de http://www.memoriachilena.gob.cl/602/w3-article124167.html

${ }^{21}$ Libros de instrucción primaria. BLD, Libro XXI, (1), 1853, p. 676. Recuperado de https://catalog.hathitrust.org/Record/000063525

RHAA v.56 n.2, 2021. ISSN: 0556-5960, ISSNe 2314-1549. CC BY-NC-SA 4.0 
estudiantes. En su Memoria sobre educación común, Sarmiento denunció la ruina de su empresa por la nueva política del gobierno, que se convirtió en el único comprador. Los juicios del sanjuanino al respecto fueron lapidarios y clamó por el cese de "este deplorable sistema" (Sarmiento, 1856a, p. 107). Según observa Subercaseaux (2010), al analizar las declaraciones del propio Sarmiento, los intentos de fundar imprentas tanto en Valparaíso como en Santiago habían sido "abortivos", ya fuera por falta de apoyo o por una protección equivocada por parte del gobierno (p. 72).

A pesar de la ruina de la empresa, Belin y su suegro se lanzaron a un nuevo emprendimiento, la imprenta El Ferrocarril, que publicó varias obras de Sarmiento. Además, constituyó una plataforma desde la cual el sanjuanino pretendía captar a los lectores de las futuras bibliotecas populares.

En 1854 el argentino tradujo el libro Esposición (sic) é historia de los descubrimientos modernos ${ }^{22}$. La obra original, Exposition et histoire des principales découvertes scientifiques modernes, fue escrita y publicada en 1851 por el científico francés Louis Figuier, quien había ideado aquel texto con la finalidad de divulgar, entre la gente común, los principales descubrimientos científicos de su tiempo. La traducción y publicación de esta obra respondía al objetivo de "formar bibliotecas locales, parroquiales o populares, llámeseles como se quiera, con tal de que haya una cosa que lleve el nombre de tales" (Sarmiento, 1854a, p.243). La propuso enseguida al rector Bello como el texto modelo para las bibliotecas populares, cuyo prólogo, no por casualidad, se titulaba "Libros para las bibliotecas populares". Exposición e historia fue, en definitiva, la presentación formal del proyecto bibliotecario ante las autoridades educacionales del país, y, a nuestro parecer, el reinicio de su propia empresa editorial.

Con el libro de Figuier como primer peldaño, la propuesta encontró una cálida y activa acogida. Miguel Luis Amunátegui calificó el plan de introducir bibliotecas populares en Chile como una "excelente idea" 23 que "todos debemos aplaudir" 24 , mientras que el rector Bello asumió como un deber "dar la noticia al Consejo de la Universidad de la loable empresa que usted tomaba a su cargo, y de lo bien calculada que me parecía su primera publicación" (Sarmiento, 1854b, p. 458). No sabemos si estas palabras

\footnotetext{
${ }^{22}$ Desde ahora Exposición e historia.

${ }^{23}$ Amunátegui, M. L. Bibliotecas populares. MEP, Tomo III, (1), 15-08-1854, p. 14.

${ }^{24}$ Amunátegui, M. L. Bibliotecas populares. MEP, Tomo III, (1), 15-08-1854, p. 15.
} 
fueron dichas con sorna al argentino, por el riesgo propio que debió correr con la inversión efectuada, pero lo cierto es que el mencionado organismo aprobó el proyecto y advirtió que el voto favorable debía "recaer en general sobre la idea de crear bibliotecas populares, i (sic) no precisamente sobre el mérito de la obra publicada" 25 .

Sarmiento había logrado cautivar la imaginación de la opinión pública y de las autoridades. Pero aún faltaba precisar cómo este proyecto debía materializarse. En su respuesta a Bello, expuso ordenadamente las condiciones para el éxito de las bibliotecas. La primera se vinculaba a la necesidad de que aquellas fueran "una institución pública, dirigida bajo un sistema general" (Sarmiento, 1854b, p. 459); en consecuencia, era deber del Estado "encargarse de abrir canales a la difusión de las luces a todos los extremos de la República" (p. 459). Las siguientes condiciones aludían a la necesidad de dotar las bibliotecas con "libros especialmente calculados para su objeto" (p. 460), y de enriquecer sus catálogos de forma paulatina y gradual. En último término se reclamaba la adopción del préstamo domiciliario, "pues es quimera que nadie ha pretendido hacer realidad el querer que los vecinos, el niño, la joven, salgan de sus casas a sentarse en bancos helados y duros, a horas determinadas, por leer un libro" (p. 460).

Expuso también, un plan de tres fases: la primera apuntaba a la selección de los libros ya existentes en nuestro propio idioma, tarea que debía ser encomendada a la Facultad de Humanidades. De ese corpus, habría que "separar todos los que, sin otra excepción que el Quijote, son anteriores al presente siglo" (Sarmiento, 1854b, p.464), debido a que:

Las ideas han esperimentado (sic) tal vuelco en estos últimos tiempos, las ciencias han dado pasos tan agigantados, la literatura se ha refundido de tal manera, que todo libro orijinal (sic) o traducido de veinte años atrás, no podría circular con éxito en nuestros tiempos ( $p$. 464).

En cuanto a "los pocos centenares de libros traducidos" (p. 464), se indicaba que toda la literatura francesa del siglo XVIII y las novelas del XIX debían ser descartadas de plano.

${ }^{25}$ Agosto de 1854. AUCH, Serie 1, 1854, p. 340. Recuperado de https://anales.uchile.cl/index.php/ANUC/issue/archive 
segundo paso para la reposición sostenida de libros para las bibliotecas, era la creación de una comisión de estilo para revisar las traducciones, con el objeto de "castigar el lenguaje, i (sic) conservar sin pedantería la pureza de la dicción castellana"26 (p. 465), y un llamado a la acción voluntaria de "todos los sujetos, ciudadanos o estranjeros (sic), que, por deseo a contribuir a la difusión de las luces, querrían consagrar su tiempo a la compilación, traducción o composición de libros adecuados" (p. 465). Finalmente, estaba el trabajo de difusión, el cual, una vez editado un determinado volumen y previo a su distribución en las distintas bibliotecas, apuntaba a imprimir y repartir varios miles de ejemplares de "una hoja suelta que contuviera noticia del contenido del libro" (p. 465). Con esta estrategia se buscaba, sin duda, captar más lectores.

Vale la pena detenerse en el tema de los libros para las bibliotecas populares, los cuales, como bien señalaba Sarmiento, debían ser "especialmente calculados para su objeto". En contraposición al sistema europeo de acumulación de libros del cual era una muestra la Biblioteca Nacional de Chile, desde El Monitor se proponía adoptar "el sistema americano de las mil bibliotecas locales, al alcance de todos, compuestas de libros de fácil i (sic) útil lectura, adecuados a todas las inteligencias (...) libros morales e instructivos, escritos exprofeso para el común de los lectores"27. Esta idea de libros hechos específicamente para "el común de los lectores" llevaba implícita una comprensión gradual y ascendente de la lectura en cuanto a práctica. En esa línea, el sanjuanino advertía a Bello sobre el peligro de que la persona no habituada a los libros, "se retraiga a acudir a esta fuente, a causa de las dificultades con que tropieza y la elevación del asunto que le está echando en cara su ignorancia" (Sarmiento, 1854b, p. 467). Por su parte, los hermanos Amunátegui (1856) planteaban que estas instituciones debían "contener un poco de todo" ( $p$. 244), aunque advertían, había que cuidarse de "los bichos maléficos i (sic) dañinos cuya propagación por ningún motivo nos conviene fomentar" (pp. 244-245).

\footnotetext{
${ }^{26}$ Esta frase rememora la polémica protagonizada en la década anterior con Bello, promotor de conservar esa pureza manteniendo la unidad de la lengua madre, en tanto que Sarmiento proponía la independencia absoluta del idioma americano. También deja entrever el carácter pragmático de la propuesta de Sarmiento, que priorizaba lo útil sobre lo erudito, y lo práctico, aunque fuera necesario castigar el lenguaje.

${ }^{27}$ Biblioteca Nacional. MEP, Tomo I, (12), 15-07-1853, p. 362. Recuperado de http://www.memoriachilena.gob.cl/602/w3-article-124167.html
}

RHAA v.56 n.2, 2021. ISSN: 0556-5960, ISSNe 2314-1549. CC BY-NC-SA 4.0 
¿Era la novela aquel bicho? ¿Cuál fue la posición de Sarmiento en esta materia? ¿El argentino pensaba aquella literatura como parte de los catálogos de las bibliotecas populares? Durante toda su vida, fue un verdadero apologeta de este género. "Novelas son las más grandes creaciones del género humano" (Sarmiento, 1856b, p. 162), llegó a sentenciar en un famoso artículo de 1856. A partir de aquello se ha argumentado que el sanjuanino era partidario de incluir esta clase de literatura en los estantes de las bibliotecas populares (Subercaseaux, 1991). No obstante, la defensa reiterada de las novelas esgrimida por Sarmiento debe ser encuadrada, como señala Planas (2009), "en los marcos de un pensamiento pragmático" (p. 72). En efecto, para el trasandino:

\section{(...) las novelas son el primer libro que despierta el deseo de leer, que deja nociones en el espíritu, y corrompiendo como se dice, rescatan a muchos del entorpecimiento que trae la falta de toda emoción comunicada por un pedazo de papel escrito ${ }^{28}$.}

Sin embargo, en referencia a las bibliotecas populares, las novelas traducidas que abundaban por esos años "no serían muy dignas de examen" para Sarmiento (1854b, p. 464) ${ }^{29}$, y la idea de incluir aquella clase de libros en los estantes de las bibliotecas populares no formaba parte de su imaginario, tal como lo deja entrever en otro de sus escritos: "Nosotros hemos pasado nuestras vidas fundando escuelas, y aconsejando fundar bibliotecas parroquiales para instrucción del pueblo, entre las que no aconsejábamos introducir novelas" (Sarmiento, 1856b, p. 163). Más allá del contenido, el cuestionamiento podría deberse probablemente a la narrativa ficticia de tales textos, que se oponía a los criterios de utilidad y pragmatismo, por los cuales abogaba el argentino.

En cuanto al financiamiento del proyecto, Sarmiento insistió una y otra vez en lo sencillo y poco oneroso que resultaba su materialización. Ya en 1853 había planteado que todo se reducía únicamente a tomar la decisión de comenzar, mediante la edición de "de mil a dos mil ejemplares de una

\footnotetext{
${ }^{28}$ Sarmiento, D. F. Bibliotecas Locales. MEP, Tomo I, (11), 15-06-1853, p. 322. Recuperado de http://www.memoriachilena.gob.cl/602/w3-article-124167.html ${ }^{29}$ Cabe acotar al respecto que una gran variedad de novelas fue traducida, la mayoría del francés, entre 1840 y 1856. Destacan Metella de George Sand; otras de militancia, como Matilde: memorias de una joven, de Eugenio Sue, y muchas de aventuras insertas en un contexto supuestamente histórico, escritas por Alejandro Dumas, Paul Feval - antes de su conversión - entre muchos otros (Medina, 2007).
} 
docena de volúmenes al año"30. Conocedor de las dificultades con las que tropezaba la edición de libros útiles, el sanjuanino pretendía involucrar a otros gobiernos americanos para financiar en forma conjunta el gasto que demandaba tal empresa editorial. No obstante, su pragmatismo lo hacía consciente de la imposibilidad de concretar aquel plan en el corto plazo. En consecuencia, los primeros pasos tenían que ser dados en soledad por el propio gobierno chileno si se pretendía avanzar con prontitud. Así, el costo de la producción "quedaría reducido para Chile, a proveer la renta anual para la edición de diez o doce volúmenes de 300 o 400 pajinas (sic), y esto como un ítem permanente del presupuesto..." ${ }^{31}$.

En septiembre de 1855, se comisionó a Silvestre Ochagavía y Miguel Luis Amunátegui para proponer "la manera más conveniente de reglamentar las Bibliotecas populares" 32 , e informar sobre las obras que deberían componerlas, "indicando el costo que demandaría su adquisición"33. En De la instrucción primaria, pueden leerse las propuestas concretas de Miguel Luis, desarrolladas junto a su hermano Gregorio Víctor (1856). Entre estas se indicaba la necesidad, en principio, de contar con una biblioteca por departamento a cargo de los preceptores, ya que se consideraba "natural que el mismo que da la instrucción a los niños, la distribuya a los adultos" (p. 241), y las reglas a adoptar para evitar el extravío o deterioro de los libros (p. 242). Las bibliotecas norteamericanas permitían la extracción de las obras solo a personas mayores de edad, avecindadas en el distrito de cada biblioteca, y solo de un volumen a la vez. Además, si se perdía el libro, debía pagarse el total de su valor, y se multaba el deterioro y la retención del libro, con la pérdida del derecho de usuario si no se abonaba. A estas normas, juzgaban los Amunátegui, había que añadir en Chile, "la de exijir (sic) para la estracción (sic) de cada obra el depósito previo de su valor; que estaría apuntado en la portada" (p. 242). Y como complemento, planteaban posibles mecanismos de financiamiento, entre los que se contaban "las

\footnotetext{
${ }^{30}$ Sarmiento, D. F. Bibliotecas Locales. MEP, Tomo I, (11), 15-06-1853, p. 325. Recuperado de http://www.memoriachilena.gob.cl/602/w3-article-124167.html

${ }^{31}$ Sarmiento, D. F. Bibliotecas Locales. MEP, Tomo I, (11), 15-06-1853, p. 325. Recuperado de http://www.memoriachilena.gob.cl/602/w3-article-124167.html 32Leyes i decretos del Supremo Gobierno: Departamento de Justicia, Culto e Instrucción Pública. AUCH, Serie 1, 1855, p. 660. Recuperado de https://anales.uchile.cl/index.php/ANUC/issue/archive

${ }^{33}$ Leyes i decretos del Supremo Gobierno: Departamento de Justicia, Culto e Instrucción Pública. AUCH, Serie 1, 1855, p. 660. Recuperado de https://anales.uchile.cl/index.php/ANUC/issue/archive
} 
apelaciones periódicas al patriotismo de los ciudadanos" (p. 257); el producto de la venta de la obra de Claudio Gay, Historia física i (sic) política de Chile; o bien, la ayuda del mismo gobierno a través de los fondos públicos.

En este contexto, cabe interrogarse cuál era el público objetivo que pretendían captar las autoridades, si apuntaban a personas mayores y no a los jóvenes y niños; por otra parte, quién era considerado como gente del "pueblo" si se debía abonar en garantía el valor del libro. Respecto a esta última cuestión, los Amunátegui (1856) especificaban que estas bibliotecas apuntaban a servir a artesanos de primera clase, jefes de taller, hacendados, comerciantes, individuos acomodados y "jente (sic) de frac" ( $p$. 243). En aquella época, argumentaban los hermanos, esas personas eran "las únicas que se encontrarían en estado de aprovecharse de ellas" ( $p$. 243). Bien vale recordar que para 1854 solo el $14 \%$ de la población mayor de siete años sabía leer.

En las décadas de 1850 y 1860, se hizo más evidente esa relación entre el sector artesanal, su instrucción y el fomento de la lectura, tal como se percibe en los Estatutos de la Sociedad de artesanos de La Serena constituida en 1862 (art. 14):

(...) el consejo directivo fundará una biblioteca en el local de la sociedad, i creará una escuela de enseñanza pública. Corresponde al mismo consejo acordar la instrucción que deba darse en la escuela, determinar el local en que funcione i velar por su buena dirección, mejora i progreso" (Citado de Fuentes Cortés, 2009, p. 46).

De acuerdo con este testimonio, parte de aquel público lo formaba esa población adulta que acudía a las escuelas nocturnas para adquirir un oficio con el cual incorporarse al trabajo fabril (Grez, 2007). Verdaderos espacios de autoeducación, estas escuelas fueron promovidas a partir de la década de 1850 por las sociedades de artesanos, la masonería y la Iglesia Católica, en un esfuerzo por encauzar una creciente inquietud social ante las transformaciones promovidas por la revolución industrial (Cavieres, 1986; Godoy, 1994; Illanes, 2003).

Finalmente, el 16 de enero de 1856 fue emitido el decreto que organizaba y reglamentaba las bibliotecas populares en Chile. 
Persuadido de que la aptitud de leer es una facultad de todo punto estéril si no hai (sic) libros sobre que pueda ejercitarse, - señalaba el Ministro de Instrucción, Francisco Javier Ovalle, en la memoria de ese mismo año - [el gobierno] ha creado bibliotecas populares en todas las cabeceras de departamentos, completando por decirlo así, nuestro sistema de instrucción primaria ${ }^{34}$.

Las observaciones y propuestas de los distintos involucrados en el proceso de gestación se plasmaron de una u otra forma en el reglamento, entre cuyos artículos destacaban: el establecimiento de una biblioteca en las cabeceras departamentales designadas por el presidente, anexada a una escuela de la zona y formada con libros proporcionados por el gobierno; la designación de los preceptores como bibliotecarios; la obligación por parte de las municipalidades de nombrar a los directores de bibliotecas, quienes ejercerían labores de censura sobre los libros donados por particulares y efectuarían inspecciones trimestrales en la biblioteca a su cargo; el establecimiento del préstamo domiciliario; la creación de un catálogo de los libros existentes y un registro de las obras solicitadas; y el deber de los Intendentes y Gobernadores de promover suscripciones y estimular el celo de los vecinos con el fin de reunir fondos para las bibliotecas ${ }^{35}$.

Tal como queda de manifiesto, el reglamento estableció la responsabilidad del gobierno de proveer los libros adecuados para las bibliotecas. Pero se planteaba ahora el dilema concreto acerca de cómo obtener tales libros. Cuando los hermanos Amunátegui (1856) se preguntaron de dónde sacar textos para organizar estas pequeñas bibliotecas, la traducción fue la respuesta evidente y natural: "Lo que el castellano no tiene, lo tiene el inglés, lo tiene el francés. Traduzcamos i (sic) adaptemos" (p. 246).

Esta resolución del problema traía aparejada no solo una crítica a la producción libresca en nuestro idioma, sino también una fuerte interpelación a la lengua española en un contexto cultural caracterizado por un rechazo y menosprecio del legado colonial. En ese sentido, no resultaba extraño que Sarmiento (1854a) considerara entre las causas del atraso de los pueblos

\footnotetext{
${ }^{34}$ Memoria que el Ministro de Estado en el Departamento de Justicia, Culto e Instrucción Pública, presenta al Congreso Nacional de 1853. MEP, Tomo II, (1), 1508-1853, p. 20. Recuperado de http://www.memoriachilena.gob.cl/602/w3-article124167.html

${ }^{35} B L D$, Libro XXIV, (1), 1856, pp. 6-8. Recuperado de https://catalog.hathitrust.org/Record/000063525
}

RHAA v.56 n.2, 2021. ISSN: 0556-5960, ISSNe 2314-1549. CC BY-NC-SA 4.0 
hispanoamericanos "esta rémora que el idioma opone a la instantánea transmisión de las ideas útiles i (sic) de las aplicaciones prácticas que de ellas hacen los pueblos que nos llevan la delantera" (p.244). En consecuencia, solo a través de la traducción se podía subsanar aquel mal:

Tenemos, pues, que llenar un vacío de nuestra lengua, que hasta hoy no es repertorio de los conocimientos que entran a formar las ideas generales de los otros pueblos, de que emanan las aplicaciones prácticas a los negocios e intereses de la vida (p.249).

La traducción, efectivamente, ocupó un lugar central en el sistema literario nacional durante esta época. La formación de un modelo literario nuevo y el momento de cambio que vivía la sociedad explicarían el protagonismo de la traducción en este periodo (Payàs, 2018). El objetivo de la empresa traductora era importar e incorporar los conocimientos y saberes producidos por las naciones más "civilizadas" del orbe. Todo este movimiento estuvo dirigido a cubrir las demandas de las instituciones educativas, a las cuales se vinculaban las bibliotecas populares. Como bien apunta Payàs (2018), "la prioridad al traducir fue la dimensión educativa-social, por encima de la estética" (p. 344). Es importante también tener en cuenta que, en comparación con los estándares actuales, la traducción durante el siglo XIX fue una labor entendida y ejecutada de forma bastante más laxa. Para que la traducción sirviera de algo "había que intervenir los textos, ya que no todo lo que decían era asimilable, ni conveniente o pertinente para la sociedad chilena" (p. 341). De allí el predominio, en este periodo, de las traduccionesadaptaciones, las cuales formaban parte de una práctica aceptada.

En este contexto, una serie de libros fueron traducidos y publicados con miras a llenar los anaqueles de las incipientes bibliotecas populares del país. En este sentido, en 1856, el ministro Ovalle señalaba:

Una de las causas que ha embarazado más la ejecución de este pensamiento, ha sido la carencia de libros a propósito en lengua española, inconveniente que ha removido el Gobierno haciendo traducir i (sic) publicar aquellas obras que con un objeto análogo se han escrito en los países europeos ${ }^{36}$.

\footnotetext{
${ }^{36}$ Memoria que el señor Ministro de Instrucción Pública presenta al Congreso Nacional. MEP, Tomo IV, (12), 15-09-1856, p. 375.

RHAA v.56 n.2, 2021. ISSN: 0556-5960, ISSNe 2314-1549. CC BY-NC-SA 4.0
} 
Amanda Labarca (1939), al referirse a las bibliotecas populares, acota que de esta época "datan las ediciones castellanas de 'Vida y viajes de Cristóbal Colon', de Washington Irving; 'Conquista de México' y 'Conquista de Perú', de Guillermo Prescott” (p. 147). Al observar aquellos títulos resulta bastante paradójico percibir que, mientras los pueblos americanos del sur deseaban huir de su pasado hispánico, el mundo anglosajón volvía la mirada hacia España (Jaksić, 2007). Las huellas de esta empresa las podemos encontrar en la Biblioteca chilena de traductores de don José Toribio Medina, de la cual se extrajo la selección incorporada en el cuadro 4.

Cuadro 4: Libros traducidos para las bibliotecas populares. Chile, 1854-1860

\begin{tabular}{|c|c|c|c|c|}
\hline Título & Autor & Traductor & Editorial & Año \\
\hline $\begin{array}{l}\text { Esposición (sic) e historia de } \\
\text { los descubrimientos modernos }\end{array}$ & Louis Figuier & $\begin{array}{l}\text { Domingo } \\
\text { Faustino } \\
\text { Sarmiento } \\
\end{array}$ & $\begin{array}{l}\text { Imprenta } \\
\text { Julio Belin } \\
\text { y Ca. }\end{array}$ & 1854 \\
\hline Cicerón & $\begin{array}{l}\text { Alphonse de } \\
\text { Lamartine }\end{array}$ & Anónimo & $\begin{array}{l}\text { Imprenta } \\
\text { Nacional }\end{array}$ & 1855 \\
\hline Cristóbal Colón & $\begin{array}{l}\text { Alphonse de } \\
\text { Lamartine }\end{array}$ & Anónimo & \multirow{3}{*}{$\begin{array}{l}\text { Imprenta } \\
\text { Nacional }\end{array}$} & \multirow[t]{3}{*}{1855} \\
\hline $\begin{array}{c}\text { Homero, Gutenberg; seguidos } \\
\text { de Bernardo de Palissy }\end{array}$ & $\begin{array}{l}\text { Alphonse de } \\
\text { Lamartine }\end{array}$ & \multirow{2}{*}{$\begin{array}{l}\text { Juana } \\
\text { Pérez }\end{array}$} & & \\
\hline Oliveros Cromwell & $\begin{array}{l}\text { Alphonse de } \\
\text { Lamartine }\end{array}$ & & & \\
\hline $\begin{array}{c}\text { Guillermo el Conquistador o } \\
\text { sea la Inglaterra bajo los } \\
\text { normandos }\end{array}$ & $\begin{array}{l}\text { Obra revisada } \\
\text { por M. Guizot }\end{array}$ & $\begin{array}{c}\text { Manuel } \\
\text { Amunáteg } \\
\text { ui }\end{array}$ & \multirow{3}{*}{$\begin{array}{l}\text { Imprenta } \\
\quad \text { del } \\
\text { Ferrocarril }\end{array}$} & \multirow{3}{*}{1856} \\
\hline $\begin{array}{l}\text { Manuel del carpintero de } \\
\text { muebles o edificios, seguido } \\
\text { del arte del ebanista }\end{array}$ & M. Nosban & \multirow{2}{*}{ Anónimo } & & \\
\hline $\begin{array}{l}\text { Origen i (sic) fundación de los } \\
\text { Estados Unidos de América }\end{array}$ & Paul Loira & & & \\
\hline Nueva biografía de Pío IX & & $\begin{array}{l}\text { Miguel de } \\
\text { la Barra }\end{array}$ & $\begin{array}{c}\text { Emilio } \\
\text { Audois } \\
\text { Librero- } \\
\text { Editor }\end{array}$ & 1857 \\
\hline Infancias célebres & Luisa Colet & & & \\
\hline La Grecia contemporánea & Edmond About & & & \\
\hline La Indica contemporánea & Ferdinand de & & & \\
\hline
\end{tabular}




\begin{tabular}{|c|c|c|c|c|}
\hline & Lanoye & \multirow{3}{*}{ Anónimo } & \multirow{4}{*}{$\begin{array}{l}\text { Imprenta } \\
\quad \text { del } \\
\text { Ferrocarril }\end{array}$} & \multirow{5}{*}{1858} \\
\hline $\begin{array}{l}\text { La Piscicultura i (sic) la } \\
\text { reproducción de las } \\
\text { sanguijuelas }\end{array}$ & $\begin{array}{l}\text { Augusto } \\
\text { Jourdier }\end{array}$ & & & \\
\hline $\begin{array}{c}\text { La vida i muerte de Sócrates } \\
\text { referida por Jenofonte i (sic) } \\
\text { Platón }\end{array}$ & & & & \\
\hline $\begin{array}{c}\text { Washington. Fundación de la } \\
\text { República de los Estados } \\
\text { Unidos de América }\end{array}$ & & $\begin{array}{l}\text { Virginia } \\
\text { Rojas }\end{array}$ & & \\
\hline $\begin{array}{c}\text { Catecismo popular sobre el } \\
\text { protestantismo i (sic) la Iglesia } \\
\text { Católica }\end{array}$ & Padre Perrone & $\begin{array}{l}\text { Francisco } \\
\text { Dou y José } \\
\text { Moragádes } \\
\text { y Gil }\end{array}$ & $\begin{array}{l}\text { Imprenta y } \\
\text { Librería } \\
\text { Mercurio } \\
\text { S. Tornero } \\
\text { y Ca. } \\
\end{array}$ & \\
\hline $\begin{array}{l}\text { La Gran Carta o el } \\
\text { establecimiento del régimen } \\
\text { constitucional en Inglaterra }\end{array}$ & $\begin{array}{l}\text { Camilo } \\
\text { Rousset }\end{array}$ & Anónimo & \multirow{8}{*}{$\begin{array}{l}\text { Imprenta } \\
\text { del } \\
\text { Ferrocarril }\end{array}$} & \multirow{5}{*}{1859} \\
\hline Revistas de Europa & A. Cochut & $s / d$ & & \\
\hline $\begin{array}{l}\text { Vidas i (sic) viajes de } \\
\text { Cristóbal Colón }\end{array}$ & $\begin{array}{l}\text { Washington } \\
\text { Irving }\end{array}$ & $s / d$ & & \\
\hline $\begin{array}{c}\text { Ensayo sobre Chile, escrito en } \\
\text { francés y publicado en } \\
\text { Hamburgo }\end{array}$ & $\begin{array}{l}\text { Vicente Pérez } \\
\text { Rosales }\end{array}$ & $\begin{array}{l}\text { Manuel } \\
\text { Miguel }\end{array}$ & & \\
\hline $\begin{array}{c}\text { El porvenir político de } \\
\text { Inglaterra }\end{array}$ & $\begin{array}{l}\text { El Conde de } \\
\text { Montalembert }\end{array}$ & $\begin{array}{l}\text { Estanislao } \\
\text { Zenteno }\end{array}$ & & \\
\hline Manual de labranza & & \multirow[b]{3}{*}{ Anónimo } & & \multirow[t]{3}{*}{1860} \\
\hline $\begin{array}{l}\text { Retratos políticos, históricos i } \\
\text { (sic) literarios del siglo XIX }\end{array}$ & $\begin{array}{l}\text { M. Hipolito } \\
\text { Castle }\end{array}$ & & & \\
\hline $\begin{array}{c}\text { Tratado completo de la } \\
\text { crianza (sic) engorda de las } \\
\text { aves domésticas i (sic) } \\
\text { conejos }\end{array}$ & W. Trotter & & & \\
\hline
\end{tabular}

Fuente: Medina, 2007.

A partir de este registro, comprobamos que entre 1854 y 1860 se publicaron 24 libros dirigidos específicamente a las bibliotecas populares. Aunque al menos tres de estas obras fueron reimpresiones de traducciones hechas en España $\left({ }^{*}\right)$, la mayoría restante fue traducida en Chile. Gran parte de estos textos fueron tomados de autores franceses contemporáneos. Entre los 
traductores, cuya generalidad se mantiene en calidad de anónimos, aparecen Domingo F. Sarmiento, Manuel Amunátegui, José Miguel de la Barra, Manuel Miquel y Estanislao Zenteno, además de dos mujeres, Juana Pérez y Virginia Rojas. Asimismo, encontramos títulos de divulgación científica, como la mencionada Exposición é historia; de contenido histórico, tales como Guillermo el conquistador o sea la Inglaterra bajo los normandos, u Origen i fundación de los Estados Unidos de América; de carácter más práctico, entre los que destacan manuales de labranza y carpintería; y obras biográficas, género que tenía una "alta misión, cual es educar a la humanidad, excitando en ella la admiración y el deseo de acercarse a los grandes modelos" (Sarmiento, 1854b, p. 467). Entre estas últimas, destacan una serie de escritos del intelectual francés Alphonse de Lamartine, que recrea la vida de hombres célebres del ámbito laico, en una época en que el género de los llamados "plutarcos" estaba en boga (Soaje y Salas, 2018).

Si consideramos las editoriales mencionadas en el listado, observamos que la Imprenta EI Ferrocarril publicó 17 de los 24 textos, los cuales representan un $75 \%$ de la muestra, si sumamos el de Julio Belin i cia. Este último punto pone de manifiesto, a nuestro parecer, la intención de Sarmiento por captar progresivamente a este público lector, al acaparar el mercado de este tipo de textos, pese a las trabas puestas por parte del Estado chileno a los proyectos editoriales del sanjuanino en el pasado.

\section{Conclusiones}

A mediados del siglo XIX se inició un proceso de modernización y expansión de la instrucción primaria en Chile. A través de la escuela se buscó expandir la cultura escrita para poder incorporar a la sociedad entera en el camino del Progreso. Pero, como bien comprendieron muchos de los impulsores de la educación, la enseñanza del alfabeto era solo un primer paso. El libro fue para ellos la verdadera herramienta de instrucción, en cuyas páginas el individuo ya alfabetizado hacía suyas las ideas y conocimientos propios de la "esfera civilizada". En consecuencia, la existencia de la escuela exigió la presencia activa del libro para encontrar su sentido. Pero el problema no se redujo únicamente al fomento de aquel, sino también a la necesidad de orientar el contenido de su lectura. Lo importante no era solamente que se leyera, sino que además se escogieran libros útiles, en la expresión de la época. Así lo demuestran los numerosos manuales para la crianza de animales, para el oficio de carpintero, para la 
práctica de la piscicultura, entre otros, editados por esa condición de "utilidad".

Es interesante destacar aquella impronta que coincidía con el ideario sarmientino, el cual apuntaba a purgar las bibliotecas, en orden a la instrucción del pueblo, de todos aquellos libros que fueran antiguos, eruditos, de origen español, de literatura francesa, y sobre todo las novelas, además de las obras de naturaleza religiosa o referidas a vidas piadosas. Era indispensable generar una literatura que se amoldase a ciertos aspectos formales, claramente esbozados por Sarmiento, como el diseño atractivo y la utilización de imágenes, además del contenido relacionado con historias, viajes, biografías y descripciones de países, o manuales para el aprendizaje de oficios y ramos, con lo que se pretendía llenar la exigencia de "fácil lectura". En este sentido, cabe acotar que esta premisa del libro útil y atractivo llegó para quedarse, e influyó hasta la actualidad en las políticas lectoras de la educación pública.

En esa coyuntura surgió como respuesta el proyecto de las bibliotecas populares propuesto por Sarmiento. Ubicadas en todas las cabeceras departamentales del país y presentando como gran novedad el préstamo domiciliario, estas bibliotecas buscaban difundir el libro en todos los rincones de la república. A su vez, a través de una selección cuidadosa de sus catálogos, los cuales debían contener obras morales, instructivas y accesibles para todo tipo de inteligencia, se intentaba orientar la lectura de los individuos. La biblioteca popular era, en definitiva, el lugar de encuentro entre la escuela, el libro y la lectura. A través de aquella institución se materializaba, en parte, aquel anhelo modernizador de la elite dirigente. "La creación de bibliotecas asegura para más tarde un elemento eminentemente civilizador"37, señalaba el visitador de escuelas de la provincia de Talca en 1859.

El ideario común de la élite dirigente y de los intelectuales de mediados de siglo, tanto liberales como conservadores, basado en la expansión de la escuela pública, había encontrado en el proyecto de Sarmiento una expresión concreta de su preocupación por continuar la instrucción de los sectores más carenciados de la población. Ello funcionaría como un medio de incorporarlos al sistema mercantil y productivo potenciado a partir del

\footnotetext{
${ }^{37}$ Memoria que el visitador de escuelas de la provincia de Talca pasa al señor ministro de instrucción pública. MEP, Tomo VIII, (2), 15-11-1859, p. 36.
}

RHAA v.56 n.2, 2021. ISSN: 0556-5960, ISSNe 2314-1549. CC BY-NC-SA 4.0 
movimiento independentista y de la apertura del país hacia los nuevos mercados extranjeros.

Esta realidad señala nuevamente el cuestionamiento acerca del público objetivo que Sarmiento pretendía atraer. En distintos escritos suyos se menciona al joven, la señorita, a los apoderados de los alumnos de las escuelas, al hombre que se inicia en la práctica de la lectura, entre otros, pero también se define de manera indirecta, a un lector hipotético, al proponer la adopción del sistema norteamericano y buscar la protección de los textos y asegurarse su devolución, por sobre la visión del lector como futuro socio estable de las bibliotecas; quizás esta falta de definición de la categoría "pueblo" sea un motivo más para explicar su posterior fracaso. Por otra parte, tal como mencionábamos anteriormente, existió una vinculación concreta entre la población adulta que buscó la instrucción en las escuelas nocturnas, y el fomento de la práctica lectora por parte de las sociedades que nuclearon a la clase obrera o se preocuparon por su educación, lo cual nos lleva a sopesar la importancia creciente de este sector popular que emergía a mediados del siglo XIX y que creció aceleradamente en la segunda mitad de la centuria, a partir de la toma de conciencia de su importancia a medida que se educaba en aquellos establecimientos.

Otra conclusión es la confluencia entre las mencionadas ideas acerca de la educación popular, los conocimientos y experiencia adquiridos por Sarmiento en el arte y en el negocio de la imprenta, y la gestión de su propio proyecto editorial junto a su socio; no en vano, le propuso a Jules Belin fundar una "imprenta colosal" que él veía como muy prometedora si lograba derrocar al "tirano Rosas". Sin embargo, tras el decreto de 1853, por causa del cual se produciría la quiebra de la empresa, el proyecto de las bibliotecas populares constituyó una nueva esperanza para reemprender el negocio, y lograr así, financiamiento para materializar sus ideas, tanto educativas como políticas a través de la publicación de sus propias obras. De acuerdo con este ideal, la quiebra no fue obstáculo para reinventar su empresa en 1854, con la edición del libro de Figuier y la propuesta bibliotecaria presentada al Consejo Universitario. Cabe destacar, en este sentido, la actitud reticente de dicho organismo, el cual acogió favorablemente esta propuesta, pero advirtió que esta aceptación no se basaba en "el mérito de la obra publicada". 
Finalmente, y aunque tanto el periodo de funcionamiento de las bibliotecas (1856-1865), como las razones que explicarían su ulterior fracaso, son cuestiones ajenas al presente artículo, cabe mencionar, a modo de epílogo, algo sobre las aparentes causas de tal fiasco.

En agosto de 1865, el Ministro de Instrucción, Federico Errázuriz (1865), exponía al Congreso tres razones que explicaban el fracaso de estas instituciones, deslindadas de los informes recibidos sobre treinta bibliotecas situadas a lo largo del país. En aquellos se argüía a lo poco adecuado de los locales, la prohibición del préstamo domiciliario (suprimido en 1863) y la falta de un horario de apertura diario. Sin embargo, Errázuriz, quitándole importancia a esas cuestiones, atribuía todo a una sola causa: lo poco arraigado que estaba el gusto por la lectura en el "pueblo". A su parecer, la puesta en marcha de las bibliotecas había sido un paso demasiado prematuro. En contrapartida, un artículo atribuido tradicionalmente a Sarmiento (1867), le imputaba el fracaso de las bibliotecas a la carencia de una selección cuidada y rigurosa de libros, la cual habría sido pensada para un lector ideal, desatendiendo por completo al lector real. Estos testimonios, contradictorios hasta cierto punto, más que aclarar la cuestión, solo siembran más dudas sobre el estrepitoso fracaso de las bibliotecas populares en Chile. Consideramos que un estudio más acucioso de las distintas fuentes existentes, cuyo contenido es, en muchos casos, enteramente inédito, puede arrojar mayor luz sobre una materia bastante desatendida por los estudios históricos.

\section{Fuentes}

Amunátegui, M. L. y Amunátegui, G. V. (1856). De la instrucción primaria en Chile: lo que es, lo que debería ser. Imprenta del Ferrocarril.

Errázuriz, F. (1865). Memoria que el ministro de estado en el departamento de Justicia, Culto e Instrucción Pública presenta al congreso nacional de 1865. Imprenta Nacional.

Sarmiento, D. F. (1841). La publicación de libros en Chile. El Mercurio. En Obras de D. F. Sarmiento publicadas bajo los auspicios del gobierno argentino. Tomo I (pp. 70-72). Imprenta y Litografía Mariano Moreno.

Sarmiento, D. F. (1844). Legislación sobre imprenta como industria. El Progreso. En Obras de D. F. Sarmiento publicadas bajo los auspicios 
del gobierno argentino. Tomo $X$ (pp. 57-68). Imprenta y Litografía Mariano Moreno.

Sarmiento, D. F. (1849a). Biblioteca Americana. La Crónica. En Obras de D. $F$. Sarmiento publicadas bajo los auspicios del gobierno argentino. Tomo XII (pp. 256-261). Imprenta y Litografía Mariano Moreno.

Sarmiento, D. F. (1849b). Aprendices de imprenta. La Crónica. En Obras de D. F. Sarmiento publicadas bajo los auspicios del gobierno argentino. Tomo X (pp. 277-279). Imprenta y Litografía Mariano Moreno.

Sarmiento, D. F. (1849c). De la educación popular. En Obras de D. F. Sarmiento publicadas bajo los auspicios del gobierno argentino. Tomo XI. Imprenta y Litografía Mariano Moreno.

Sarmiento, D. F. (1854a). Libros para las bibliotecas populares. En Obras de D. F. Sarmiento publicadas bajo los auspicios del gobierno argentino. Tomo XII (pp. 241-251). Imprenta y Litografía Mariano Moreno.

Sarmiento, D. F. (1854b). Bibliotecas populares. Carta al rector de la Universidad de Chile. El Monitor de las Escuelas Primarias. En Obras de D. F. Sarmiento publicadas bajo los auspicios del gobierno argentino. Tomo IV (pp. 458-469). Imprenta y Litografía Mariano Moreno.

Sarmiento, D. F. (1856a). Educación común. En Obras de D. F. Sarmiento publicadas bajo los auspicios del gobierno argentino. Tomo XII. Imprenta y Litografía Mariano Moreno.

Sarmiento, D. F. (1856b). Las novelas. El Nacional. En Obras de D. F. Sarmiento publicadas bajo los auspicios del gobierno argentino. Tomo XLVI (pp. 169-153). Imprenta y Litografía Mariano Moreno.

Sarmiento, D. F. (1867). Bibliotecas Populares. En Obras de D. F. Sarmiento publicadas bajo los auspicios del gobierno argentino. Tomo XXX (pp. 321-333). Imprenta y Litografía Mariano Moreno.

Sarmiento, D. F. (1886). Imprenta Belin Hnos. y Cia. El Censor. En Obras de D. F. Sarmiento publicadas bajo los auspicios del gobierno argentino. Tomo VIII (pp. 26-29). Imprenta y Litografía Mariano Moreno. 


\section{Bibliografía}

Aedo-Richmond, R. (2000) La educación privada en Chile: un estudio histórico analítico desde el periodo colonial hasta 1990. Ril.

Baeza Ruz, A. (2018). Bosquejo compendioso del sistema de enseñanza mutua. Cuadernos chilenos de historia de la educación, (9), p. 180190.

Baeza Ruz, A. (2019) Contacts, collisions and relationschips. Britons and Chileans in the Independence era, 1806-1831. Liverpool University press.

Cabo, J. (2016). Sarmiento y la imprenta: políticas editoriales de autor en torno a Facundo (1845). Actas de la XXVIII Jornadas de Investigadores del Instituto de Literatura Hispanoamericana Facultad de Filosofía y Letras (UBA). Buenos Aires, abril.

Cabo, J. (2018). Sarmiento y el proyecto editorial de la Imprenta de Julio Belin \& Cía. Actas de la XXX Jornadas de Investigadores del Instituto de Literatura Hispanoamericana Facultad de Filosofía y Letras (UBA). Buenos Aires, marzo.

Campobassi, J. S. (1975). Sarmiento y su época. Editorial Losada.

Caruso, M. (2010). Latin American independence: education and the invention of new polities. Paedagogica Historica: International Journal of the History of Education, 46 (4), 409-417. https://doi.org/10.1080/00309230.2010.493164

Cavieres, E. (1986) Grupos intermedios e integración social: La Sociedad de Artesanos de Valparaíso a comienzos del siglo XX. Cuadernos de Historia 6, 33-47.

Chacón, J. (1924). Una carta sobre los hombres de 1842. Atenea, 68 (203), 193-201.

Cherniavsky Bozzolo, C. (2015). La religión en letra de molde. Iglesia y prácticas de la lectura en la Arquidiócesis de Santiago 1843-1899. Ediciones Universidad Católica.

Collier, S. (2005). Chile: la construcción de una república 1830-1865. Políticas e ideas. Ediciones Universidad Católica. 
Cucuzza, H. R. (dir.) y Pineau, P.(codir.) (2018). Historia de la enseñanza de la lectura y la escritura en Argentina. Del catecismo tradicional a la Razón de Mi Vida. Miño y Dávila editores.

Egaña Baraona, M. L. (2000). La educación primaria popular en el siglo XIX en Chile: Una práctica de política estatal. DIBAM.

Fuentes Cortés, M. (2009) Educación Popular en la Sociedad de Artesanos de La Serena: Escuela Nocturna 1874-1884. Universum, 24, 1, 2009, p. 42-57. http://dx.doi.org/10.4067/S0718-23762009000100004

Godoy Orellana, M. (1994). Mutualismo y educación: las escuelas nocturnas de artesanos, 1860-1880. Última década, 2 (2), 42-53.

Gómez Hernández, J. A. (1993). La preocupación por la lectura pública en España: las bibliotecas populares. De las Cortes de Cádiz al plan de bibliotecas de María Moliner. Revista General de Información y Documentación, 3, 55-94.

González Miranda S. (2002) Chilenizando a Tunupa. La escuela pública en el Tarapacá Andino 1880-1990. DIBAM, Centro Barros Arana.

Illanes, M. A. (2003) La revolución solidaria. Las sociedades de socorros mutuos de artesanos y obreros: un proyecto popular democrático. 1840- 1910.LOM.

Labarca, A. (1939). Historia de la enseñanza en Chile. Publicaciones de la Universidad de Chile.

Lastarria, J. V. (1878). Recuerdos literarios. Imprenta de la República de Jacinto Núñez.

Lyons, M. (2012). Historia de la lectura y la escritura en el mundo occidental. Editoras del Calderón.

Mayorga, R. (2010) Un nuevo camino de la A a la Z: enseñanza y aprendizaje de la lectoescritura en la escuela primaria chilena del siglo XIX, Pensamiento educativo, (46-47), 265-284.

Medina, J. T. (2007) [1925]. Biblioteca chilena de traductores (1820-1924). Centro de Investigaciones Diego Barros Arana - DIBAM.

Muñoz, J. C. (2019). Aproximación histórica a la formación de las bibliotecas populares en Chile desde mediados del S. XIX: el caso de la Bibliotecas popular de Curicó, 1856-1865. Cuadernos chilenos de historia de la educación, (11), 28-44. 
Muñoz, L. y Oelker, D. (1993) Diccionario de Movimientos y grupos literarios chilenos. Desde el Movimiento literario de 1842 hasta el teatro de la década del '50. Cuadernos Atenea, Editorial de Concepción.

Newland, C. (1991). La educación elemental en Hispanoamérica: desde la independencia hasta la centralización de los sistemas educativos nacionales. Hispanic American Historical Review, 71 (2), 335-364. https://doi.org/10.2307/2515644

Pas, H. (2013). Sarmiento, redactor y publicista: con textos recobrados de El progreso (1842-1845) y La crónica (1849-1850). Ediciones UNL.

Payàs Puigarnau, G. (2018). Traducción e ideario de la nación. En G. Rojo de la Rosa, C. Arcos y B. Subercaseaux (Coords.). Historia crítica de la literatura chilena. Volumen II La era republicana: Independencia y formación del Estado Nacional (pp. 333-357). LOM Ediciones.

Planas, J. (2009). Para un catálogo atractivo: libros y políticas editoriales para las bibliotecas populares. La propuesta de Domingo Faustino Sarmiento. Información, Cultura y sociedad, (20), 63-81. https://doi.org/10.34096/ics.i20.806

Planas, J. (2017). Libros, lecturas y sociabilidades de lectura. Una historia de los orígenes de las bibliotecas populares en la Argentina. Ampersand.

Poblete, J. (2017). La lectura popular: entre la biblioteca y la hoja suelta. Taller de Letras, (61), 51-64.

Santos Tornero, J. (1889). Reminiscencias de un viejo editor. Imprenta de la librería del Mercurio.

Schapochnik, N. (2018). Livros e leitura para o povo: ascensao e decadencia da Bibliotecas Populares no Império Brasileiro, 18701889. Historia y Espacio, 14 (51), 199-229. https://doi.org/10.25100/hye.v14i51.7275

Serrano, S. (2016). Universidad y Nación. Chile en el siglo XIX. (2ª . ed.). Editorial Universitaria.

Serrano, S. y Jaksic, I. (2000). El poder de las palabras: la Iglesia y el Estado liberal ante la difusión de la escritura en el Chile del siglo XIX. Historia, (33), 436-460.

http://dx.doi.org/10.4067/S071771942000003300010 
Serrano, S.; Ponce de León, M. y Rengifo, F. (2012). Historia de la educación en Chile (1810 - 2010) Tomo I: Aprender a leer y escribir (1810-1880). Taurus.

Soaje de Elías, R. y Salas Fernández, M. (2018). José Bernardo Suárez: un agente de la educación popular y su visión sobre la instrucción primaria en Chile (1867). Revista de Historia y Geografía, (39), 49-72. https://doi.org/10.29344/07194145.39.1692

Stuven, A. M. (2008). El exilio de la intelectualidad argentina: polémica y construcción de la esfera pública chilena (1840-1850). En C. Altamirano y J. Myers (Coords.). Historia de los intelectuales en América Latina I. La ciudad letrada, de la conquista al modernismo (pp. 412-440). Katz.

Subercaseaux, B. (1991). D.F. Sarmiento y el libro en Chile. MAPOCHO, (30), 10-15.

Subercaseaux, B. (2010) [1993]. Historia del libro en Chile. Desde la Colonia hasta el Bicentenario. (3ª. ed.). LOM Ediciones.

Toro Blanco, P. (2018). Ideas políticas educacionales en Chile, C. 1810-C. 1980. En I. Jaksic y S. Gazmuri (Editores). Historia política de Chile, 1810-2010. Tomo IV: Intelectuales y pensamiento político (pp. 103131). Fondo de Cultura Económica. 